\title{
Between Economic Burden and Cultural Dignity: Belis in the Marital Custom of the NTT Society
}

Komunitas: International Journal of Indonesian Society and Culture 9(1) (2017): 92-103

DOI:10.15294/komunitas.v9i1.8672 (C) 2017 Semarang State University, Indonesia p-ISSN 2086 - 5465 | e-ISSN 2460-7320 http://journal.unnes.ac.id/nju/index.php/komunitas

\section{Siti Rodliyah ${ }^{1}$, Andrik Purwasito ${ }^{2}$, Bani Sudardi ${ }^{3}$, Wakit Abdullah ${ }^{4}$}

'Universitas Muhammadiyah Kupang , Indonesia

1,2,3,4Universitas Sebelas Maret, Surakarta, Indonesia

Received: March 2016; Accepted: August 2016; Published: 30 March 2017

\begin{abstract}
The indigenous marital system giving belis 'bride price' practiced by the East Nusa Tenggara (NTT), Indonesia, is one of the Nusantara marital custom phenomena that today has developed and raised issues of both pros and cons which deserves critical scrutiny from Cultural studies and Anthropological perspective. Both perspectives facilitate the critical standpoint of the NTT society's mindset summarized in the cultural or customary marriage rules requiring a marriage with belis. This study revealed that in the attitude towards belis, the East Nusa Tenggara women agreed and taken for granted the construction of their reality and power production through various discourses. Current practice of belis raises the economic capitalism up to the identity contestations. Lately, the essence and value of belis have changed and are likely to be more commercial. Even some may view it as mere a symbol and customary fixtures, such as in the region of Lamaholot imposing the elephant tusks, and the Allor society with their Moko as the payment methods of belis. Belis has left biggest challenge for the communities who are not able to afford higher bride-price objects, this consequently lead to a more emerging unlawful marriages as a resistance against the unresolved poverty problems.
\end{abstract}

\section{Keywords}

belis; economic capitalism, marital custom, payment; symbols

\section{INTRODUCTION}

Indonesian people are a nation built on the foundation of diversities in terms of the culture and the society. One of the cultural diversities is reflected in the way a marriage is traditionally carried out by the communities. The marital system of the indigenous people in the East Nusa Tenggara is popularly known for adopting marital system of bride price, traditionally called 'belis'. Belis is usually provided by the family of the groom to the bride and her family. Just a simple say, belis can be interpreted as giving the material to relatives or siblings at certain events. In general, it is always associated with the provision of money or goods at a marriage ceremony. Marriage system in the tradition of NTT people generally embraces a patrilineal genealogical system (following the paternal line) and regards the clan or tribe as an important identity. In principle, every marriage will form an alliance and involves a system of exchange of assets between families or tribes.

People of East Nusa Tenggara (NTT) conceptually enact belis as a primary condi-

\footnotetext{
Corresponding author

Jln. KH. Ahmad Dahlan No 17, Kupang

Nusa Tenggara Timur, Indonesia, 82558

Email

rodliyahs@rocketmail.com
} 
tion in their marital tradition. The uniqueness of belis as a symbolic form of a dowry is neither pay with money nor with gold, but elephant tusk, like many found in regions around the East Flores. Belis has to be paid by a groom to the bride as the one who will be his wife. The amount of Belis is determined by agreement of both the bridegroom's families. For the East Nusa Tenggara people, belis is one of the required attributes encompassing a series of traditional wedding ceremony, which is still well-maintained till this day. East Nusa Tenggara Province consists of six major islands, namely Flores, Sumba, Timor, Rote, Sabu and Alor commonly known by the acronym FLOBAMORA. These districts have different perceptions regarding the essence and media of belis payment. The word belis here is derived from the root word of 'buying', which means purchasing or sort of obligation to give and receive something (as dowry) to the family of the woman before undergoing the wedding procession with a cash payment or a debt (Abdurrasyid \& Hidayat 2008, pp. 414).

The payment of belis becomes an important validity prerequisite of the marriage and is believed to be a unifying symbol of man and woman as husband and wife, as a key condition for clan attestation displacement / wife's tribe into the husband's, as well as compensation for the services of the bride's parent for raising her until marriage comes. Similar facts about belis, bride-price have been extensively practiced in most societies of Africa and Asia to validate their traditional marriage etc. (cf. Thiara and Hague 2011, Baluku 2012; Albertyn 2013; Mukova 2012; Ojilere 2015). Traditionally, the East Nusa Tenggara people implements belis in their marital system as a means to honor the bride and her family. Typically, belis consists of the marriage contract, in which material goods (generally in the form of cows or elephant tusks and other animals), or (currently may have changed with money) paid by the groom to the bride's family as a kind of exchange for the bride.

The customary marriage system enacting the bride-price or dowry is essentially a form of transaction that is mostly practiced and deeply rooted in the model of marriage systems in Africa and Asia (Claassens 2013; Lipi 2016; Nasrin 2011; Rautenbach 2010). The custom of transacting and spending expenditure, cattle, and source from the groom's side to the bride and her family of the East Nusa Tenggara people is known as paying for belis. Lately, the essence and value of belis have changed and are likely to be commercial. Even some may still view it as only a symbol and custom fixtures, such as in the region of Lamaholot imposing the elephant tusks as the payment method of belis. In addition, belis is customary deemed to be the compensation to the bride's family which seems to be eroded over time that is quite significantly changed due to the influence of economic capitalism. Of course, people of NTT and their customary law of marriage that centralizes belis will be targeted to being trading commodity for customs purposes which successfully impose public expenditure and their financial resources. Not to mention the problems of the economic situations that have been long happened in the province. Although some groups would see belis as a form of protection for women by giving them respect, status and recognition in the society, but in the process of implementation, it subordinates the women for it is often found that belis associates with the domestic violence within households. On the other hand, it is a case of the people's mentality that would feel valued in the community if in an event of marriage wherein the groom could not pay the determined amount of belis (cf. Thiara and Hague in 2011 on the case of dowry).

This study aims to develop an understand the issues surrounding the practice of marital system implementing bride-price, traditionally called belis as a perquisite for marriage validity. It seeks to provide understanding of both historical and critical viewpoints on the procurement of belis objects which is customarily given by the groom's sides to the bride and the family. It is an attempt of disclosing the reality in the marital system of the East Nusa Tenggara society through both historical reflections and the perspective of cultural and anthropological 
studies. The discourse approach is used as an underlying method which does not always control what is said on the specific socio-cultural situation, but also control who, where and when a phenomenon is considered as a discourse. Additionally, any arising phenomenon is called a discourse.

Relevant studies related to belis and social lives of NTT people have been researched by a number of historians and anthropologists such as Frederik Fernandez (2010) in his dissertation "Social Capital In Customary Events of Marriages \& Deaths Among the Ethnic Lamaholot and People of Nagi in East Flores", who alluded the system of marriage with likat telo but with the emphasis that this marriage system is undergoing adjustments as a result of the changes and demands of the times. As a result, people who get married is no longer on the path that has been set by custom. This is because belis has shaped the elephant tusks circulation outside of the system and perceived in terms of the economical side as a burden for those who give and receive mutual parties. Tenabolo Dade (2012) in his article "the dynamics of belis in the society of Rote Ba'a marriage customs in village of Mokdale Lobala, Rote Ndao district" reviewed the understanding of the meaning of belis and the shifting values have been the triggering aspects to the various forms of injustice, especially against women both before and after marriage. Rubenson Banfatin (2012) in his thesis titled "Shifting Meaning of Belis (A Study On Ethnic Community of Sikka In Kota Kupang, East Nusa Tenggara Province)" revealed that the current practice of paying belis is no longer properly done, it rises a new insights which tends to be negative and people started to blame their own customs. Many transactions on behalf of the indigenous practices have turned to increase the amount of belis properties.

Cultural development due to order change and the political system as well as the impact of the past colonization brought some significant shifts in the meaning of belis. If we are to trace through the historical records, political contacts and trade between the kingdoms of NTT with Portuguese government during the colonial era in the 16th century, it implies that belis is strongly influenced by elements of feudalism absorbed by the society of NTT (Lewis 1988, p. 7; Kunst 1942, p. 1-2). The phenomenon of the implementation of belis in the form of elephant tusks practiced for generations by the people of NTT in Lamaholot, Adonara and Sikka-Flores is the fruits of past trade through barter system (Bomas p. 2016). This is also confirmed by the statement of the head of customs in the West Adonara related to the history of the use of elephant tusks as belis. It originated from commercial trade made by the society living in the west of Adonara with foreigners across nations (such as India and Africa), which exchanged the results of their local sources with a few sticks of ivory (Oceannaz 2008; Jianqin 2016; Mawere 2010; Rudwick 2015). The phenomenon of the entering of elephant tusks to the local customs through a barter system as sacred objects is quite reasonable. In fact, geographically, there has never been both history and the existence of elephants living throughout areas of the East Nusa Tenggara. However, the changes on the belis objects and the cultural values undeniably gave significant impacts on the public enthusiasm but some may have seen this as a perfect situation to economically be advantageous. There are the presence of symptoms which often occur in the life of the community, such as the disruption of the balance between social units of society; loosening of family relationships within the community; and the emergence of protracted conflicts among the cultural supporters (Sudjoko et al 1983, pp 36).

This study is designed in a qualitative-descriptive analysis to understand the ethnic point of view, especially perspectives concerning the marital system adopted by the East Nusa Tenggara society, the decision making process and the effects of their psychological states, which engage both economic and social well-being matters. The fieldwork was carried out in East Nusa Tenggara encompassing the islands of Flores, Sumba, Timor, Rote, Sabu dan Alor; 
constructed in the acronym FLOBAMORA. The selection of the sites for this study was determined as much by variety of materials use and perceptions of the societies regarding with belis to validate marriage in customs. In addition, research sites were selected because of the willingness of individuals to cooperate, the convenience of the situation for the researcher and contacts already established by the researcher.

A conventional technique is applied to build rapport with the target groups, the researcher is involved in the people's routine daily activities. Data collection applied in-depth interview method, semi-structured in-depth interviews to 15 informants, including males, females, couples, informal leaders (tetua adat) or village leaders. Interviews were private and confidential. a tape recorder in conjunction with note taking was a useful means of covering the full dimension of the conversation. The recorded information was transcribed in full. These files of transcribed interviews constituted the main information for this study. The majority of interviews were conducted in Bahasa Indonesia, the national language of East Nusa Tenggara.

\section{Overview to the Practice of Belis}

Belis has been a socio-cultural phenomenon for the people of East Nusa Tenggara, an inseparable part of the customary marriages which also cause consequences if it is ignored. Taking significant function as sort of binding transaction, the payment of belis in this marital system can be made either with cash at the course of the marriage ceremony or through installment method within the indefinite time. Additionally, the determined amount and methods for paying belis is considered a debt if it cannot be done at the course time. However, if the groom and his family have not paid the bride price yet and or he who indebted to the transaction has passed away before time, the repayment will be charged to his children and the grandchildren. In case, anyone of the practitioners deliberately ignored the marital system of belis shall receive moral, social and psychological sanctions enacted by the community (Allerton, 2004: 345).

The implementation of belis as a part of the customs and culture of the NTT people is strongly influenced by the customary values inspired by the indigenous belief system called Marapu (Anggraeni 2003). Unlike the general belief systems, Marapu has two important roles in the lives of indigenous peoples in the province. First, traditional belief of Marapu plays a pivotal role as a way of life, local trait, parameter of both character and attitudes of the people which especially originated from Sumba. Marapu itself at least functions as traditional rules or laws. The rules can be defined as a guideline to behave according to the way the ancestors' lives, so called Marapu. The rules are, therefore, not only concerned with intellectual character and just understood to the people alone, but with the whole pattern of life.

People of Sumba interpret belis as suppression of cultural values, but it is also regarded as something which is not termed as the "exchange price" which nominally countable. It was strongly associated with the local beliefs (local genius) of Sumba people (Marapu). The belief philosophically concerns on the idea that when humans move from one cosmos to another, the cosmic place of origin will be empty so that it becomes imbalance. For women who are ready to get married and was paid for her belis, it is believed that her cosmos (of the family) is imbalance. Belis given to the woman is believed to be the replacement for the void of the cosmos place of origin (Kapita 1976, pp. 15).

Marriage system implementing belis indicated that the East Nusa Tenggara marital tradition is exogamous ${ }^{1}$ which adopts a genealogical patrilineal system (following the paternal line of family). The philosophical meaning of belis lays on its function as a binding tie between the $\mathrm{fam}^{2}$ or two different clans who wish to build and main-

1 In this system according to the customary law, a person is required to marry with someone of outside the family clan.

2 Marga or fam is a kinship group, either matrilineal or patrilineal, members of a clan believe that they came from the same ancestors, members of this genus are generally adopted system of exogamy (Abdurrasyid \& Hidayat, 2008) 
tain a good and mutual life relationships. Essentially, belis may take different forms (the agreement depends on specific regions) which can be both material (material) and immaterial encompassing the functions and symbolic practice.

In addition to money, there are other forms of belis in East Nusa Tenggara ranging from gold, silver, elephant tusks (East Flores), Moko / nekara bronze (Alor), or livestock such as horses, buffalo, cows and pigs (Sumba), sofren / golden plate (Belu). The amount of bride price is determined by the social status of the girl, the higher the social status of the girl the higher amount of values has to be paid. However, the value of bride price is changeable according to negotiations between the male and female families. It is culturally deemed a pride, the men had managed to pay off his belis demand at the course of time. Belis can be regarded as a unifying symbol of male and female as a bonding husband and wife, and also become part of the ratification of the displacement of wife's clan / tribe to husband's clan / tribe, as well as being deemed to be the compensation for life services of the bride's parents who have been raising their daughter until adulthood.

In a customary marriage of NTT people, the existence of belis is regarded as a symbol of appreciation and recognition to the dignity of a woman. In other words, belis becomes an indicator for women and men in this culture being respected and appreciated. This is as reflected in the Floresian proverb (a region in NTT):"dua naha nora ling, nora weling, loning dua utang ling labu weling, dadi ata lai naha letto wotter" (each female has a value, has a price, while her gloves and clothes also have value and prices, so that every man must pay for them). The phenomenon of belis as a tradition has come to be ironic if the existing social condition remains unstable. In actual fact, whenever the practice of belis is done under the payment intended to enriching one party against the other, it shall lessen the cultural sacredness. Consequently this raises negative perceptions either from the people themselves or people of other ethnicity. The community of today started to blame customs. Many practices in the name of custom abused this system; people tend to increase the demands for belis that exceed the limits of a person or group for it is pride and prestige (Banfatin 2012). Objects refer to belis used to reflect symbols for power and social status by slow degree started to be ignored by the method of payment using cash as the replacement.

In deciding the appropriate forms of belis, it cannot be separated from the role of mentality that had been built long before the existence of today's modern society. The imagery use of elephant tusk as payment method of belis realized by the subjects as the echo or reflection,experience, copy, or reconstruction of perceptual experiences that actually happened in the past (inspired by predecessors) allows them to anticipate the future experience, either desirable or even tend to be scared because. In addition, the spiritual experience of the local community, indigenous religion called Marapu is deemed to have a core reason for practicing the tradition so as to produce a normative conception and consequent. Imagery thus plays an immense role in the beliefs and communities' characters related to the East Nusa Tenggara marriage system requiring the payment of belis.

\section{Elephant Tusks as a Unique Method of Belis Payment}

The most difficult conversation between the woman's family (the bride) and men (the groom) pertain to the matters of how many tusks should be given to the bride's family as a method for paying the belis to legally claimed her as the man's wife. In that context, the social status of the girls sets benchmarks in determining the more/less, long/short, and large/small of the required elephant tusks. If the wife to be comes from a family with high social status, the number of elephant ivory should be numerous and lengthy. If the woman came from a simple family, the number and size of the tusks could be compromised.

Elephant tusks as a payment method of belis found in traditional institutions had 
been exist for hundreds of years ago. Some others were brought from outside by the nomads. If the marriage occurred among women from Lamaholot with men from outside the tribe and takes place overseas, the tusks are currently convertible into cash. However, if the wedding took place in Flores, belis should be in the form of tusks. Elephant tusks in a language of the Lamaholot called bala. There are seven types of reinforcements, among others, bala huut (the tusks length corresponding arm span of adults from the fingertips right to the fingertips left), bala five one (tusks measured by fingertips right to left hand of adults), and reinforcements relieved excavation (tusks criteria along fingertip until cleavage) (Moedjiono 2011, pp. 13).

In the custom of Lamaholot society, common tusks are not measured according the official size, i.e., centimeters. Local people only use the size fathoms or adult arm span. In the agreement on belis, female's family determines the number and size of the tusks. As for the so-called family they are made up of parents, brother, and uncle (mother's brother). The number of belis is based on the tusks paid by the girl's father when he proposed marriage to her mother using tusks. The specified numbers of tusks for a woman ranges from 3-7 rod. Number seven sticks usually prevail among nobles or dignitaries. Ordinary people require generally three sticks. (Communication with Laga, August 21, 2015). Currently the prices of tusks in the East Nusa Tenggara varied in average, it ranges around 13 million to 100 million rupiah per-sticks. Therefore, it is not easy to get it. The elephant tusks began to decrease in the rate around Lamaholot since they are mostly sold out of Flores or cut up as materials such as bracelets, rings, and other objects of jewelry (Ama 2010).

The practice of paying belis with elephant tusks as a symbolic media among the majority of the East Nusa Tenggara people is not because there are a lot of elephants in the land of East Flores, but it is the remaining result of a transaction or trade barter system enacted in early society. At that time, trading was conducted by va- rious merchants out of archipelagos like Sumatra, or with people across countries such as Malaysia, and India in exchange for the elephant tusks with the local resources of spices, antiques, etc. (Samsudin Beleng Personal Comm. 27/09/2016). Besides, it is also historically known that Catholicism came along with the arrival of the Portuguese to the East Nusa Tenggara regions, they came initially just intended to trade, but as the time passed by, the spread of religion was then performed.

Oscar M. Pareira, a historian and cultural observer of Sikka (personal comm. 19/o9/2016) reported that the elephant tusks which were spread in Flores for the benefit of the current custom are originally brought from Malacca. It is what lies behind the reason of why the tusks' prices remain higher and become an antique and rare commodity which is then assigned as the symbol for belis (bride price). There are three types of tusks to be kept till today, the length (twohanded adults) allegedly came from Africa, the shorter (one-handed) was from India and the shortest one (about 30 centimeters) obtained from Malay island (Java and Sumatra). These tusks began to be traded in around the East Nusa Tenggara. The commercialization of the customs and traditions by using goods as a prerequisite for the validity of a marriage in this region turns the public as a mere consumers continue to be used by the broker market of tusks. This is according to Oscar (19.09.2016) is one of the government's fault which only gives less attention to aspects of culture. "They just think the development on the physical and material sides", he said.

\section{Moko, another unique method for paying belis}

Besides being known as the Land of Nusa Kenari, the Alor Island is also known for the Land of thousands Moko. For the communities living in Alor, Moko plays an important role. The ownership of the number and types of specific Moko enhance the social status. Moko or called bronze nekara is the pre-history cultural objects. According to experts, archaeologists and historians, the making 
technology of Moko in Alor comes from the bronze technology in Dongson, Northern Vietnam, which at the end, this technology was spread to other parts of Southeast Asia, including to the island of Alor. Moko is characteristically like a drum with diameter of 40 centimeters to 60 centimeters and 80 centimeters to 100 centimeters height and are in various forms. In general, Moko is oval shaped like a small drum, but there is also a large drum-shaped. Decorative patterns to each type of Moko vary depending on the manufacturing time and are very similar to bronze objects in Java during the Majapahit era. In the usage, Moko has a variety of functions. But in the early use, Moko took function as a traditional musical instrument employed during the ceremonies and other traditional art events. Usually, Gong and Moko were the two instruments played as accompaniment to the traditional dances. In addition to being the traditional musical instrument, Moko serves as a community economic exchange to Alor people.

Moko was an exchangeable instrument into certain goods through barter system. This once led to inflation at the Dutch colonial government; the Dutch turned the new system to limit the circulation of Moko in Alor Island. Over time, the function of Moko gradually changed. The current use of Moko served as symbolic form of belis 'bride price' as well as a symbol of social status. In Alor society wedding customs, Moko have been extensively used as means of media payment for belis which must be provided by the groom to his future wife (Lapuimakuni, 2014).

In specific, if the groom's side could not provide a single Moko, then they have to borrow the Moko to indigenous elders (tetua adat). Thing to remind, the borrowing is not free, because the groom's family must replace it with high amount of money. Indeed, the price of each Moko is greatly varied, depending on the size of the produced Moko, the year in which it is manufactured as well as the curved patterns. But for the people of Alor, Moko cannot be measured by any amount of money for Moko has its own position and value in social interface among the
Alor society. Certain kind of Moko has some kind of social status in society, i.e., Moko Malei Tana and Moko Itkira. The belonging of both Mokos primarily enhance the social status and a privileged position of the owner. Additionally, both Moko are influential in traditional community leadership of the Alor society (Personal comm. with Yohana 2016, 47 years old).

\section{Women and Social Identity in the practice of Belis}

The need to be recognized as part of a particular community, accepted and appreciated by their social groups are the most basic human needs (Baumeister \& Leary 1995; Leary \& Baumeister 2000). NTT communities who uphold their hereditary customs have always seen the practice of belis as an implementation of the noble values transmitted hereditary from predecessors. In order to run these values, the NTT people tried to put themselves at best to be seen as members in their social group, even though the assessment on a claim "being a good member" may be different or even potentially override other rights. The tradition of belis as well as the custom demands, also the cultural values have many evaluative gap against the tradition bearers who, either consciously or not, have put aside the valuable cultural values. The issue which is considered the most difficult among the bridegroom is at the discussion of how many tusks should be given by the man's side to-belis the wife. In that context, the social status of a person is used as benchmarks to determine more / less, long / short, and large / small of the tusks.

Traditionally, belis represents the dignity of both parties, both men and women as the giver and receiver. Belis teaches each social group to live with mutual respect in giving for gifts. In the development of socio-political life of the NTT people at this time, the existence of belis and its meaning shiftings, people interpret belis as a symbol of prestige. Lately, the essence and value of belis have changed and are likely to be commercial. The study concluded that the ownership of belis in a fam or clan can be seen as enhancing identity of community 
and social image of the practitioners. The symbolic deconstruction on the symbolic meanings of belis cover the practice and understanding of the media objects which has been shifted to the ideology of consumerism and capitalism strengthening the economy and education, legitimizing the ideology of gender, supporting the family prestige contestation and triggered poverty situation in the province.

In the context of belis tradition, the women's identity construction within patriarchal society has successfully led them to act and perceive against their structural position and their own will in the society. In short, there is no freedom for women to make their own choices or decisions related to their lives. The women were just considered traditionally as strong, rational and mighty if she had been able to live a double burden. Such a view happens due to the perception that people tend to act as 'a passive audience'. The East Nusa Tenggara women, oppressively agreed and taken for granted the construction of reality and power production through various discourses that are present in the absence of reflective consciousness as well as to provide diverse symbolic action against the tradition. Even the achieved education has not successfully provided intellectual awareness to understand the nature of the self and the environment in the process of a change.

\section{Historical Impact on the Symbolic Values of Belis}

The enforcement of belis in the traditional marriage of NTT had begun before the entry of the Portuguese missionaries. Belis was formerly symbolized in the form of betel-nut which was thought as a symbol or a sign of the bond of charity and unity between husband and wife as well as the bonds of brotherhood between the two families. However, after the entry of Portuguese, the elephant tusks were legitimized as the customary objects, former method of paying belis was with Sirih Pinang which is currently replaced by elephant tusks that reflect symbolic power of the NTT ancestral communities. The background of using elephant tusks as belis object was there were a lot of complaints from women in Sikka who were treated unfairly by their men. Men who have a lot of free treasure remarried another girl(s) and abandoned their wives and not given any household expenses. Therefore, during the reign of King Sikka named Agnes da Silva in the 17th century who at the first time regulated the customary marriages using belis. The king tightened the rules for belis in order to enhance protection to the women. The communities in Sikka felt that belis was a sign of honor and respect for women and their families. The objects of belis formerly reflect symbols of power and social status which now have mostly been ignored by the people; even many of the modern people did conversion to belis into money. The socio-political life developments of Sikka people have shifted the meanings of belis, current people interpret belis as a symbol of prestige. The dominant factor affecting the shift in the meanings of belis is: a symbol of prestige, economic value and objects of belis (cf. Banfatin 2012).

The shift of views of the NTT people towards belis makes it an intermediary symbol for both commercialization practice and religious customs. The movement has shifted to a sense of profanation on cultural attributes; this is no longer perceived to contain sacred cultural message but as the fulfillment of the industrial market needs. The survival of the traditional marriage using belis raises the dilemma between upholding the noble values of culture or instead to contribute on the increasing poverty levels in the province. No doubt that people are literally still stuck on symbols rather than interpret the essence behind the symbols. Even when the symbol of indigenous traditions are replaced into a market system, local wisdom of belis tradition becomes a means of supporting the economic needs. The serious impact of these events is the more frequent and explicit phenomenon of capitalist exploitation of the succeeding generations and the improper use of cultural symbols. It is in line with Soekanto's opinion (1990, pp. 20) that the social and cultural changes are always closely related to econo- 
mic growth. Similarly, an economic growth in the region will result in changes of many public institutions.

In cultural frame of thinking, the change on the symbolic meanings of belis covers the practice and understanding which has been shifted to the ideology of both consumerism and capitalism. Of course, the situation reinforces the economic capitalism up to identity contestations, the struggle over the ideology of gender, supporting the family prestige contestation and triggers poverty situation in the province. In some regions such as Lamaholot, the elephant tusks have been agreed through generations for being the object of belis in each customary marriage. Such traditional marriage imposing the society with the elephant tusks at the marriage time is determined by the social strata of the people. The NTT communities typically pay their bride price by two to seven stick of tusks, and sometimes up to nine sticks of tusk, though the case might be rare. In addition, the amount for each procuring tusk is, therefore, influenced by lineage, education, social, economy, employment, and the beauty of their daughters. Thus, the higher strata of the girls the more number of tusks must be preliminarily paid by the prospective groom to the girl's family.

\section{Did the Orientalism values of Belis shift into Commercialization?}

Concerning the specific objects traditionally deemed to manifest high value such as the elephant tusks, in this sense, the public perception toward belis leads them nothing but 'the passive audiences'. To some degree, the East Nusa Tenggara people agree and take for granted the social construction of reality and power production through various existing discourses amidst the absence of reflective consciousness through symbolic action that againsts the negative impact of the tradition. For the people, the education should be a foundation to the enlightment and intellectual awareness to understand the individuals' characters and their environment in the process towards a change. In evaluating the marital system and its practice of providing resources for bride- price 'belis', it is interesting to bring the case into the historical fact to understand why the traditions have been constantly maintained . I argue that the phenomenon of belis deserve to be critically seen from the historical scene as the impact of what Edward Said called 'orientalism".

Orientalism $^{3}$ is a historical construction on society and the Eastern culture as "alien", sometimes even seen as a kind of alienation. Orientalism is both inaccurate and if equated with racism, rough and brutal attitudes. It is then interestingly and more appropriately to call orientalism as a discourse that shows fundamental different sense between "us, the West" and "them, the East people". Orientalism is the mastery of the hegemonic nature. Said adopted methods used by Michel Faucault that Orientalism is constructed through discursive construction. It has three theoretical implications in the work of Edward Said (1995, pp. 272-273), namely: First, Said shows that ideology operates not only through the form of consciousness but also through practical material goods. Secondly, there are tightly interwoven intricate and complex between politics and science. The knowledge of the West, either directly or indirectly is a form of colonialism discourse. Third and the most controversial is that orientalism was "selfgenerating" in nature or evolved in itself. An important point here is that the knowledge of the West was not only creating knowledge but also containing a description of what is visible and what is in fact happening. Based on Said's perspective (1995) in expressing criticism of Orientalism, anything produced by the investigation of the West towards the East (Said exemplifies Western invasion to Islam), which is in the context of the practice of bride price can be equated with the im-

3 Orientalism, etymologically derived from the word 'orient', means east and the ethnological meaning refers to the nations. In addition, geographically refers to things that are eastern. While the term 'orientalism' interpreted as a method or methods of use to understand the eastern world, based on the place which is specialized in the western people or can be simply understood as a way of thinking is based on the distinction of ontological and epistemological made between the East and West. 
position of elephant tusks as belis payment method in the East Nusa Tenggara. In this sense, only the situated event tends to benefit the West (the Portuguese). This is due to the effort made to reinforce the domination and control of the West on various East regions along with a variety of its available resources. In addition, attempt to academically investigate the frame of Orientalism also see the variety of existing weaknesses in Eastern societies, whether they are conscious or not.

In accordance with the obtained ethnographic data, almost every traditional elders recounted the story of elephant tusks for belis payment as an impact of the Portuguese colonial period. It is highly appropriate if we could link this situation with the concept of Said's Orientalism which transformed a new rule of imposing the society procuring the elephant tusks for payment method of bride-price essentially commercializes belis. To an extent, due to this commercialization, there certainly emerges new job opportunities to brokers of the elephant tusks. The sense of commercialization on customary marriage practice with the bride price always goes to the bargaining process pegged to the amount of elephant tusks is quite vividly marked as a business trade. Whatever the reason, a lot of concern on the economic aspects was the most powerful and dominant throughout the determining process on criteria for specific size and number of the provided tusks. There are strong indications that the family feel they had to raise his daughter from childhood to adulthood, thus for all these tiring efforts, the groom deserves to pay off all the burdens. Above all the consequents, there is a tendency among the parents to increase the cost of raising their daughters. The higher the level of education and social levels of the children and parents the higher the value for belis that should be paid by the groom's side. Conversely, the lower the levels of social and educational level of children and parents the lower the economic value for the belis.

Exception to the previous indicators, the attitudes of seeing the marital system as a thriving field of commercialization was primarily motivated by the flow of globalization which is followed by other changing aspects of lifestyle, popular culture, mass media. It is also caused by lack of understanding and taking a deep concern on the sanctity and sacred values of belis as a way of preserving local wisdom of the people. Again, the remaining impact of consumer culture and society affected at least the major population of the Nusa Tenggara which finally lead them into individualistic in nature, it strengthens both materialistic and global nature of the people. The consumerism seen from the procurement objects of belis which validates the customary marriage was the result of the shifting of values in the concept of giving belis as a gift into symbolic value. This shift occurred because of the lifestyle, image, and prestige that concern modern lifestyle. At the end, the cultural consumerism becomes commonplace and considered to be human's primary need.

Aglobal culture is commonly supported by ideology of capitalism. Global capitalism constructs people's worldview; it directs people to see everything as nothing but a commodity of use to build up the differences and identities among members of a society. Consumption in the global capitalist society is not just a use value but also engages symbolic values (Piliang 2011, pp. 238).

\section{What are the Impacts of the shifting values of Belis?}

As the time develops and the global world impact embraced by the society, the mindset of the modern society in the East Nusa Tenggara is adjusted towards the changes. The demands for belis required by the bride's family slowly free from binding, though by no means the practice of belis contract is totally abolished (Octavian 1985, pp. 41). People of NTT continuously maintain belis for it has been practiced hereditarily and thus becomes sacred. The sacredness point of belis makes it not be overlooked. For example, the demand for bride price has to be standardized to the belis had once been received by the bride's mother (by her father) at the time of the marriage proposal taken place (Haning 2006, pp. 14; TPKK 1989, pp. 16-17). 
It was then perceived as a burden for generations of modern society in the province, "the practice of marriage with the bride price is considered to be a burden to be met, , especially for those who are among the poor families because of their limited assets to repay the belis"(Smeru Research 2006: 26).

On the other hand, one of the biggest remaining problems from the practice of belis is the more emergence of unlawful marriage as a resistance against the unresolved poverty problems. A marriage without careful preparatory work will lead to poor families in economic terms. Related to the statement, in general, the NTT people ironically hold a wedding party at a very expensive cost. In contrast when it is viewed in economic terms, the average populations of NTT are living under the medium economic level and the income per capita is very low. The individual income of each worker in East Nusa Tenggara range about Rp. 35, ooo per-day. This suggests that the eastern region of Indonesia, especially East Nusa Tenggara and West Nusa Tenggara are classified into region with the highest poverty index. i.e in 2005 , there is $67 \%$ to $45 \%$ rates of malnutrition. In this case as informed by Suryahadi et al, (2005 as cited in the Overseas Development and Research Institute) that the practice of marital tradition with belis played a major role in increasing the poverty rate.

\section{CONCLUSION}

Cultural dynamics due to the political system as well as the impact of the past colonization left particular influences on the meaning of belis. The objects of belis formerly reflected symbols of power and social status which now have mostly been ignored by the society. The increasing price for belis which should be paid by the male and his family is determined by the education and social status of the females. The East Nusa Tenggara women, oppressively agreed and taken for granted the construction of reality and power production through various discourses. Current practice of belis raises the economic capitalism up to the identity contestations.
Lately, the essence and value of belis have changed and are likely to be more commercial. Even some may view it as mere a symbol and customary fixtures, such as in the region of Lamaholot imposing the elephant tusks, also the Allor society with their Moko as the payment methods of belis. Belis has left a biggest challenge for the communities who are not able to afford higher bride-price objects, this consequently lead to more emerging unlawful marriages as a resistance against the unresolved poverty problems.

\section{REFERENCES}

Abdurrasyid \& Hidayat. 2008. Kamus Bahasa Arab (Kontekstual Aplikatif). Pustaka, Bandung.

Albertyn, C. 2013. Religion, custom and gender: marital law reform in South Africa. International Journal of Law in Context, 9(3), pp. 386-410.

Allerton, C., 2004. The path of marriage: Journeys and transformatiion in Manggarai, eastern Indonesia. Bijdragen tot de Taal-, Land-en Volkenkunde, 16o(2/3), pp.339-362.

Ama, K., (2010, July 15). Gading Gajah, Mahar yang Membebankan, Blogspot Post. Retrieved from: http://sains.kompas.com/ $\mathrm{read} / 2010 / 07 / 15 / 02342896 / G a d i n g . G a j a h . M a-$ har.yang.Membebankan

Anggraeni, S.A., et al. 2003. Perempuan Sumba dan Belis. BAPPEDA Kabupaten Sumba Timur. Waingapu

Banfatin, R. A., 2012. Pergeseran Makna Belis (Sebuah Studi Pada Masyarakat Etnis Sikka Di Kota Kupang Propinsi Nusa Tenggara Timur). [Shifting Meaning Belis (A Study of Ethnic Communities Sikka in the City of Kupang, East Nusa Tenggara)].Thesis. Universitas Gadjah Mada, Yogyakarta.

Baumeister, R. F., \& Leary, M. R., 1995. The Need to Belong: Desire for Interpersonal Attachments as a Fundamental Human Motivation. Psychological Bulletin, 117(3), pp. 497-529.

Claassens, A., \& Smythe, D., 2013. Marriage, land and custom: what's law got to do with it?. Acta Juridica, 2013(1), pp. 1-27.

Dade, T. Y., 2012. Dinamika Belis dalam Adat Perkawinan Masyarakat Rote Ba 'A Di Kelurahan Mokdale Kecamatan Lobalain Kabupaten Rote Ndao. Humanis, 1(1), pp. 1-8.

Development Challenges in East Nusa Tenggara (2006 October/December). SMERU - The SMERU Research Institute. Retrieved from: www. smeru.or.id

Jianqin, W. U., 2016. Social and Cultural Functions of Lisu Costumes. Cross-Cultural Communication, 12(7), pp. 1-4.

Kapita, O. H., 1976. Masyarakat Sumba dan Adat Istiadatnya. BPK Gunung Mulia, Jakarta. 
Lapuimakuni, A., (2014 October 27). Moko dalam Tradisi Masyarakat Alor. Retrieved from: http://kupang-airport.com/detail/wisata/ moko-dalam-tradisi-masyarakat-alor-

Leary, M. R. \& Baumeister, R. F., 200o. The nature and function of self-esteem: Sociometer theory. Advances in experimental social psychology, 32, pp. 1-62.

Lipi, R. K. 2016. Dignity and Empowerment: An Exploration of the Microcredit Experiences of Women in Rural Bangladesh. Journal of International Women's Studies, 18(1), pp. 230.

Mawere, M., \& Mawere, A. M., 2010. The changing philosophy of African marriage: The relevance of the Shona customary marriage practice of Kukumbira. Journal of African Studies and Development, 2(9), pp. 224.

Mukova, M., \& Mangena, F., 2012. Ethical Implications of Missionary Christianity and the Emergence of Chibarirwe African Initiated Church in Colonial Zimbabwe: A Cultural Rights Discourse. Western Journal of Black Studies, 36(2), pp. 169

Nasrin, S. 2011. Crime or custom? Motivations behind dowry practice in rural Bangladesh. Indian Journal of Gender Studies, 18(1), pp. pp. 27-50.

Oceannaz, (2008, October 24 ).Komunitas Adonara Barat - Kabupaten Flores Timur [Western Adonara Communities- Eastern Flores Regency]. Retrieved from: https://oceannaz.wordpress.com
Ojilere, A., \& Chuan, G. C., 2015. Learning from the Indian Judiciary: New Directions for Securing Nigerian Women's Right to Dignity. Asian Women, 31(1).

Piliang, Y. A., 2011. Dunia yang Dilipat: Tamasya Melampaui Batas-batas Kebudayaan. Matahari, Bandung.

Rautenbach, C. 2010. Celebration of Difference: Judicial Accommodation of Cultural and Religious Diversity in South Africa. International Journal of Diversity in Organisations, Communities $\mathcal{E}$ Nations, 10(2).

Ritzer, G., 1975. Sociology: A Multiple Paradigm Science. Boston.

Rudwick, S., \& Posel, D,. 2015. Zulu bridewealth (ilobolo) and womanhood in South Africa. Social Dynamics, 41(2), pp. 289-306.

Said, E.W., 1995. Orientalism: Western Conceptions of the Orient with a new afterword. Penguin, London.

Thiara, K., \& Hague, G., 2011. Bride-Price and its Links to Domestic Violence and Poverty in Uganda: A participatory Action Research Study'. Women's Studies International Forum, 34(1), 550-561

Wallem, F. D., 2004. Injil dan Marapu, BPK Gunung Mulia, Jakarta.

Wanti, K., 2014. Representasi Kebudayaan Masyarakat Suku Lio dalam Novel Ata Mai. Jurnal NOSI, 2(7).

Yewangoe, A. A., 1980. Korban dalam Agama Marapu. LITBANG PGI, 8(4) 